\title{
The potential sugar replacements in the development of low calorie Roselle (Hibiscus sabdariffa L. 'UKMR-2') pickles
}

\author{
Roshita Ibrahim ${ }^{1}$, Mohamad Faez Adenan ${ }^{2}$, Mohd Nizam Lani ${ }^{2 *}$ \\ ${ }^{I}$ Department of Chemical Engineering Technology, Faculty of Engineering Technology, \\ Universiti Malaysia Perlis (UNIMAP), Malaysia \\ ${ }^{2}$ School of Food Science and Technology, Universiti Malaysia Terengganu (UMT), Malaysia
}

\begin{abstract}
This study was carried out to determine the effect of sweeteners xylitol, stevia (rebaudioside-A) and stevia blend (mixture of stevia, maltitol and sorbitol) as sugar replacement in the production of roselle pickle (Hibiscus sabdariffa L.) based on sensory evaluation (acceptance tests), physico-chemical properties and microbiological quality of the pickle. From the sensory evaluation test, it showed that among all the sweeteners used, the formulation of roselle pickle using xylitol as a sugar substitute gave the most accepted sweetener compared to stevia blend and stevia (rebaudioside-A). The value of $L * a *$ and $b *$ for the colour of roselle pickle were different for formulations containing sweeteners compared to roselle pickle containing sugar (control). Roselle pickle with xylitol showed higher in total soluble solids than from the roselle pickle with stevia blend and stevia (rebaudioside-A). Total calories in roselle pickle that were formulated with sweeteners gave more than 3 times less calories than roselle pickle with sugar (control). From this study, the pH value, texture, ash, crude fiber, ascorbic acid and anthocyanin contents of roselle pickles prepared using these three sweeteners showed no significant different $(p>0.05)$. The microbiological quality done also showed that there was no detected growth of microorganisms in all the pickles.
\end{abstract}

Keywords: Roselle pickles, sweeteners, sensory acceptability, physico-chemical characteristics, microbiological quality

\section{Introduction}

Roselle or Hisbiscus sabdariffa L. is a plant of the Malvaceae family which has many applications, especially the red calyx, often processed into various food products such as juices, jams, jellies, seasonings and food colouring. In addition, people in India usually take advantage of the fiber from roselle plants as a material in textile manufactures (Musa et al., 2006; Herti et al., 2009). The introduction of roselle in Malaysia is due to the high content of anthocyanin, vitamin $\mathrm{C}, \mathrm{B}_{1}, \mathrm{~B}_{2}$ and $\mathrm{B}$ complex in roselle calyces (Musa et al., 2006).

It was also reported that, vitamin $\mathrm{C}$ content in roselle calyces was $2.5,3$, and 9 times higher than the blackcurrant, grapes and oranges, respectively (Musa et al., 2006). In addition, it is also high in minerals such as potassium, calcium, phosphorus and iron (Musa et al., 2006). The importance of its nutritional value and good health impact have made raw materials from this plant as potential crop to be utilized for making cosmetics, pharmaceutical, snack and other healthy products. Although many researches have been done on roselle in other countries, the utilization and usage of roselle in certain applications in food industries in Malaysia remain limited such as limited reports on roselle pickles in literature.

Pickling is one of the traditional methods of food preservation (Barbara, 2002). It is a preserving process that can be applied to vegetables, meat, fish, eggs, fruit and even nuts by soaking them in brine containing salt and acid and sometimes sugar. It also can enhance the flavour of the item being preserved, and can transform the food item to be pickled. The quality of pickle depends on the quality of raw materials. In most cases fruit is best pickled when slightly under ripe (Anon, 2011).

According to Malaysia Food Act 1983 and Food Regulations 1985, pickle shall be the clean, sound vegetable or clean, sound fruit or a combination of these, preserve in salt, vinegar, citric acid, fumaric acid, lactic acid, malic acid, tartaric acid or any combination of these, with or without nut, sugar and spice. It may be dried. It may contain permitted preservative, colouring, flavouring, and food conditioner. Sweet pickles are cured pickles that are packed in vinegar solution with sugar or suitable nutritive sweetening ingredient. Pickles made by direct acidification are termed "fresh pack" and are not fermented. They are combined with vinegar and spices and then pasteurized (Hui et al., 2004; Roberts et al., 2005).

At this moment, researchers in University Malaysia Terengganu (UMT) and University Malaysia Perlis (UNIMAP) had developed roselle pickle with sweet and sour taste (Ibrahim et al., 2014) and this product had been received many recognition from university and national level. Roselle pickles are sweetened by incorporation of a lot of sugar which eventually contributed to the increased in calories content and resulted in unhealthy food product if consumed in large amount or more than necessary. Therefore, to improve and diversify the existing product, the use of sweeteners to replace sugar was researched in order to produce 
healthier product with low calorie as well as to suit the needs of diabetic patients and customers who concerned with their health.

In this study three sweeteners were used as sugar replacements in the development of low calorie roselle pickles which were xylitol, stevia (rebaudioside-A) and stevia blend (stevia + maltitol + sorbitol). Roselle pickle made with sugar was served as control. The sensory acceptability, physico-chemical and microbiological properties of these roselle pickles were determined.

\subsection{Materials}

\section{Materials and methods}

Roselle calyces from UKMR-2 variety at maturity stage 3 were used in this study. All the ingredients used in the preparation of low calorie roselle pickles were from the food grades. The chemicals used for the physico-chemical and microbiological analyses were from the analytical grades.

\subsection{Roselle pickle preparations}

Firstly, the seeds of roselles were removed from calyces and the calyces were then cut into five pieces based on the five sepals of each calyx. After that, the calyces were washed thoroughly with chlorinated tap water and drained. Next, the calyces were soaked in brine solution for two days. After two days, the salts solution was drained and the calyces were then filled in sterilized glass jars until three quarter full. Pickling solution (vinegar, sugar/sweetener and calcium) was poured into the jar and leaving about $1.5 \mathrm{~cm}$ headspace. Lastly, the jars were tightly closed. The roselle calyces were left to soak in the pickling solution for one week. After a week, the roselle pickles were ready to be eaten and analysed.

\subsection{Sensory evaluation}

The sensory evaluation was done based on the acceptability for the attributes of colour, texture, taste (sweet-sour and aftertaste) and overall acceptability of the pickles. All of the samples were coded with three digits number. Thirty untrained panels from University Malaysia Terengganu were randomly chosen to evaluate the samples based on seven point hedonic scales (1-dislike extremely, 4-neither like nor dislike and 7-like extremely).

\subsection{Physico-chemical properties}

(i) Colour: Roselle pickles' colours were analyzed using Konica Minolta chromameter. The L* (lightness), a* (red-green) and $b^{*}$ (yellow- blue) values were recorded from three pieces of sample.

(ii) Texture: The firmness of roselle pickles from different treatments were determined with a Stable Micro System, TA.XTplus texture analyzer. The P2N needle probe was used. The maximum positive value (firmness) was recorded for each sample.

(iii) $\mathrm{pH}$ : The $\mathrm{pH}$ of roselle pickles were measured using $\mathrm{pH}$ meter in triplicate for each treatments.

(iv) Total soluble solid (TSS): Total soluble solid contents in roselle pickles of different treatments in triplicate were determined in ${ }^{\circ}$ Brix using hand- held refractometer.

(v) Total calorie content: The total calorie content in roselle pickles were measured following the standard procedures of Leco AC-350 bomb calorimeter.

(vi) Ash content: The ash content was determined according to the AOAC (1990). The samples were placed into muffle furnace at $550^{\circ} \mathrm{C}$ for $6 \mathrm{hr}$.

(vii) Crude fiber content: Crude fiber content determination was based on the AOAC (1990) method with a slight modification using Fibertec 2021 FiberCap ${ }^{\mathrm{TM}}$ System.

(viii) Ascorbic acid: The amounts of ascorbic acid in the pickles were determined according to the method of Jagota and Dani (1982), using UV-Vis Absorption Spectrophotometry.

(ix) Anthocyanin: The amounts of anthocyanin in the pickles were determined using UV-Vis Absorption Spectrophotometry at $520 \mathrm{~nm}$ based on delphinidin-3-glucoside in $\mathrm{pH} 1$ buffer.

\subsection{Microbiological quality}

The microbial analyses were done on roselle pickles using different sweetening agents at $10^{-1}$ to $10^{-3}$ dilutions using pour-plate methods on PCA for aerobic plate count, acidified PDA for yeast and mould count, Baird Parker Agar (BPA) for Staphylococcus aureus count, MRS Agar (Lactobacillus Agar acc. to de MAN, ROGOSA and SHARPE) for Lactobacillus count and also MPN for coliform count (Bell et al., 2005).

\subsection{Sensory evaluation}

\section{Results and discussion}

There was no significant different in the attributes of colour, aroma and texture of the roselle pickles prepared using different sweetening agents (Table 1). According to Bond (2007), Bond et al. (2006) and 
Saltmarsh (2000), xylitol has 'sugar-like' sweetness; this might be the reason why the mean score for acceptability of sweet-sour taste for roselle pickles between control and xylitol were almost similar i.e. 5.6 and 5.5 respectively. Xylitol also has no aftertaste (Saltmarsh, 2000). This resulted in roselle pickle prepared with xylitol had no significant different ( $p>0.05$ ) with control. Jenat and Jan (2007), Yamaomoto et al. (1994) and Kusakabe et al. (1992) stated that stevia extract (stevioside) is sweet but it has a slightly bitter and unpleasant note of aftertaste. However, stevia extract (rebaudioside-A) had less bitter aftertaste compared to stevioside. This factor caused the panels to give lower acceptability score for the attribute of aftertaste as well as for overall acceptability.

Table 1: The sensory acceptability of roselle pickles prepared using different sweeteners

\begin{tabular}{lllllll}
\hline Sweetening agents & \multicolumn{5}{c}{ Sensory attributes } \\
\cline { 2 - 6 } & Colour & Aroma & Texture & $\begin{array}{l}\text { Sweet-sour } \\
\text { taste }\end{array}$ & Aftertaste & $\begin{array}{l}\text { Overall } \\
\text { acceptance }\end{array}$ \\
\hline Control (sugar) & $5.6 \pm 0.89^{\mathrm{a}}$ & $4.7 \pm 1.36^{\mathrm{a}}$ & $5.5 \pm 0.86^{\mathrm{a}}$ & $5.6 \pm 0.61^{\mathrm{a}}$ & $5.3 \pm 0.58^{\mathrm{a}}$ & $5.6 \pm 0.56^{\mathrm{a}}$ \\
Xylitol & $5.4 \pm 0.77^{\mathrm{a}}$ & $4.8 \pm 1.23^{\mathrm{a}}$ & $5.2 \pm 1.03^{\mathrm{a}}$ & $5.5 \pm 0.51^{\mathrm{a}}$ & $5.2 \pm 0.65^{\mathrm{a}}$ & $5.6 \pm 0.57^{\mathrm{a}}$ \\
Stevia (rebaudioside-A) & $5.2 \pm 0.59^{\mathrm{a}}$ & $4.2 \pm 0.83^{\mathrm{a}}$ & $5.0 \pm 0.67^{\mathrm{a}}$ & $4.7 \pm 0.76^{\mathrm{b}}$ & $3.5 \pm 0.73^{\mathrm{b}}$ & $4.1 \pm 0.86^{\mathrm{c}}$ \\
Stevia blend & $5.3 \pm 0.66^{\mathrm{a}}$ & $4.3 \pm 0.91^{\mathrm{a}}$ & $5.1 \pm 0.61^{\mathrm{a}}$ & $5.2 \pm 0.68^{\mathrm{a}}$ & $3.7 \pm 0.79^{\mathrm{b}}$ & $4.6 \pm 0.73^{\mathrm{b}}$ \\
\hline
\end{tabular}

Values are mean \pm standard deviation $(\mathrm{n}=30)$. Means followed by the same letter are not significantly difference $(p>0.05)$. For each attribute, a higher value represents higher acceptability on a $1-7$ scale.

\subsection{Colour}

Table 2 shows that the colour ( $L^{*}$ value) of roselle pickles using sweeteners were significantly higher (lighter) compared to control. The $\mathrm{L}^{*}$ of xylitol and stevia blend were significantly higher than stevia (rebaudioside-A) and control. For a* values, the intensity of red colour for roselle pickles prepared using stevia blend was significantly the highest, followed by xylitol, stevia (rebaudioside-A) and lastly control. Mean while for $\mathrm{b}^{*}$ values, stevia blend and xylitol showed significantly $(p<0.05)$ higher values followed by stevia (rebaudioside-A) and control showed the lowest yellow intensity.

Table 2: The colour ( $\mathrm{L}^{*}, \mathrm{a}^{*}, \mathrm{~b}^{*}$ values) of roselle pickles prepared using different sweeteners

\begin{tabular}{|c|c|c|c|}
\hline \multirow[t]{2}{*}{ Sample } & \multicolumn{3}{|c|}{ Colour values } \\
\hline & $\mathbf{L}^{*}$ & $a^{*}$ & $\mathbf{b}^{*}$ \\
\hline Control (sugar) & $21.05 \pm 0.45^{\mathrm{c}}$ & $13.40 \pm 4.98^{\mathrm{c}}$ & $2.62 \pm 1.52^{\mathrm{c}}$ \\
\hline Xylitol & $26.82 \pm 0.49^{\mathrm{a}}$ & $23.61 \pm 0.45^{\mathrm{ab}}$ & $6.33 \pm 0.39^{\mathrm{a}}$ \\
\hline Stevia (Rebaudioside-A) & $22.86 \pm 1.14^{\mathrm{b}}$ & $18.70 \pm 0.86^{\mathrm{bc}}$ & $4.26 \pm 0.16^{\mathrm{b}}$ \\
\hline Stevia blend & $26.75 \pm 0.48^{\mathrm{a}}$ & $26.50 \pm 1.22^{\mathrm{a}}$ & $6.51 \pm 0.29^{\mathrm{a}}$ \\
\hline
\end{tabular}

Values are mean \pm standard deviation $(\mathrm{n}=3)$. Means followed by different letter are significantly different at $p<0.05$.

\subsection{Texture}

Figure 1 shows that there was no significant different $(p>0.05)$ for the texture of all the roselle pickles. These were due to the same amount of calcium used (as a firming agent) in each formulation. The calcium not only functioned as a firming agent to improve the texture, but it also fortify for fruit pickle (Saltmarsh, 2000). Calcium ions form cross-links or bridges between free carboxyl group of the pectin chains, resulting in strengthening of cell wall (Garcia et al., 1996) and firmer the texture.

\section{$3.4 \quad \mathrm{pH}$}

The $\mathrm{pH}$ of roselle pickle was around $\mathrm{pH} 2$ to $\mathrm{pH} 3$ (Figure 2). Results also showed that there was no significant different $(p>0.05)$ in $\mathrm{pH}$ for all the different sweeteners used. The growth of bacteria was restricted at this $\mathrm{pH}$. Most pathogens cannot grow in high acidic food especially at $\mathrm{pH}$ below 3 and food is considered safe when the final $\mathrm{pH}$ is 4.6 or below (FDA, 2001). This mean, the pickles produced were safe to be consumed. 


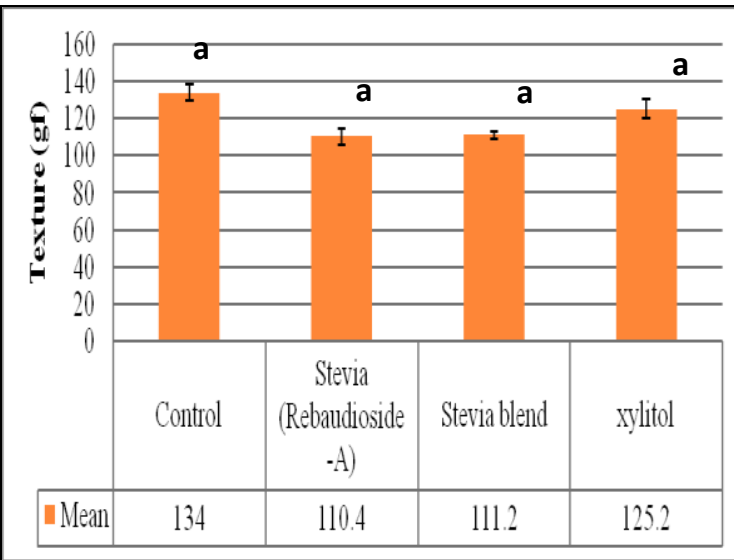

Figure 1: The texture (firmness) of roselle pickles prepared using different sweeteners

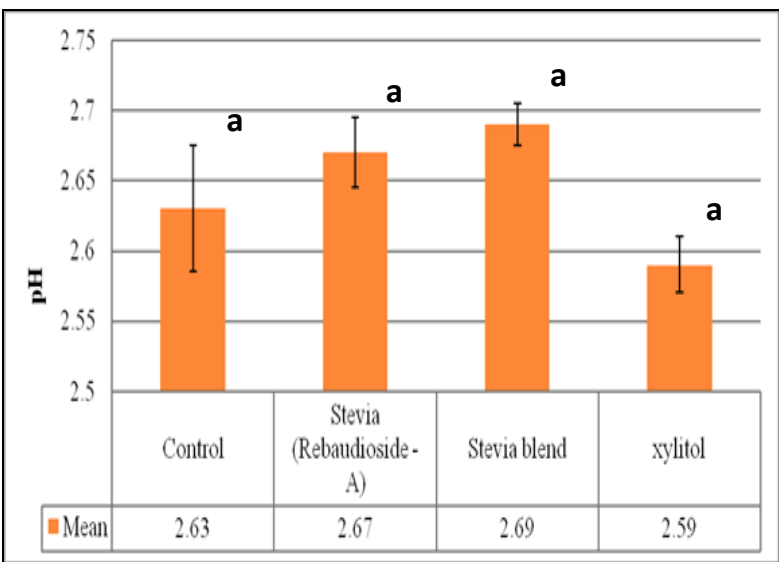

Figure 2: The $\mathrm{pH}$ values of roselle pickles prepared using different sweeteners

Values reported in means $(\mathrm{n}=3)$. Means followed by same letter are not significantly different at $p>0.05$.

\section{5}

Total Soluble Solid

Figure 3 shows that there were significant differences $(p<0.05)$ in the total soluble solid for all the roselle pickles prepared using different sweeteners. Control pickle contained significantly the highest value of TSS followed by xylitol, stevia blend, while stevia (rebaudioside-A) had the lowest value. The total soluble solid values were seemed to be directly proportional to the concentration of sweeteners used in the production of roselle pickles.

\subsection{Total calorie content}

There were significant differences $(p<0.05)$ in the calorie content among all the roselle pickles prepared using different sweeteners. Pickle using sugar (control) had significantly the highest calorie content (287.93 $\mathrm{kcal} / 100 \mathrm{~g})$ followed by xylitol $(83.68 \mathrm{kcal} / 100 \mathrm{~g})$, stevia blend $(2.23 \mathrm{kcal} / 100 \mathrm{~g})$. While, pickle using stevia (rebaudioside-A) as sugar replacement had the lowest calorie content $(0.14 \mathrm{kcal} / 100 \mathrm{~g})$ (Figure 4). The calorific values of roselle pickles were directly due to the different type of sweeteners and the concentration of sweetener used as sugar replacement where the calorie value was contributed by the sweetener per $1 \mathrm{~g}$, where $1 \mathrm{~g}$ of sugar contributes $4 \mathrm{kcal}$, and $1 \mathrm{~g}$ of xylitol gives $2.4 \mathrm{kcal}$ (Bond, 2007; Bond et al., 2006; Malcolm et al., 2006). However, Stevia is known as non-calorie sweetener (Noor Syahira, 2010; Jenat and Jan, 2007). But "stevia blend" used contributed a few calories due to the presence of maltitol and sorbitol, where for each $1 \mathrm{~g}$ of maltitol and sorbitol the caloric content was $2.4 \mathrm{kcal}$ (Malcolm ${ }^{1}$ et al., 2006; Malcolm $^{2}$ et al., 2006).

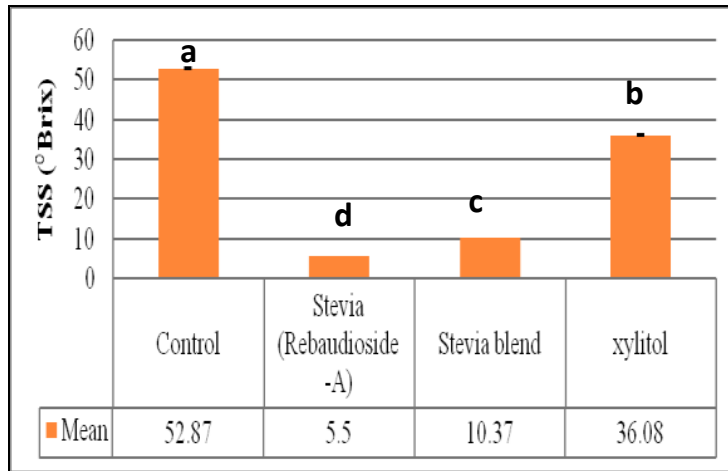

Figure 3: The TSS values of roselle pickles prepared using different sweeteners

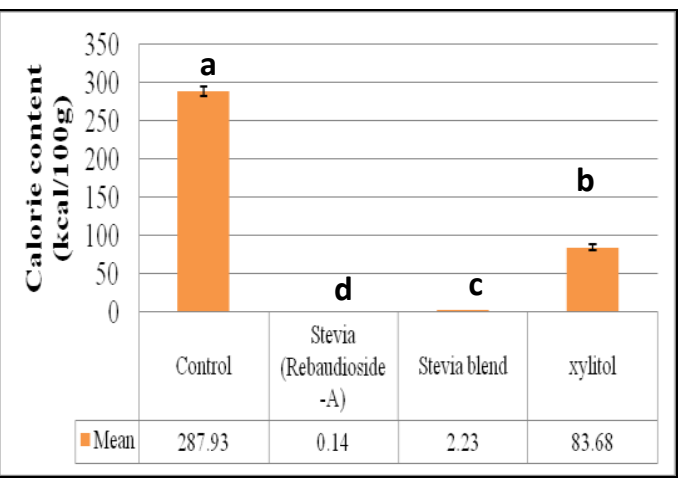

Figure 4: The calorie content of roselle pickles prepared using different sweeteners

Values reported in means $(\mathrm{n}=3)$. Means followed by same letter are not significantly different at $p>0.05$.

Figure 4 shows that roselle pickle using sweetener had more than 3 times less calorie content compared to roselle pickle using sugar (control). Based on the Fifth A table (rule 18C) in Malaysian Food Act 1983 and Food Regulation 1985 and List 1 for conditions of nutrient content for purpose of dietary claims, foods shall be not more than $40 \mathrm{kcal}(170 \mathrm{~kJ})$ per $100 \mathrm{~g}$ (solids), can be claim as a low energy/calories. For the claim of free energy/calories, food shall be not more than $4 \mathrm{kcal}$ per $100 \mathrm{~g}$. This shows that roselle pickle containing stevia blend and stevia (rebaudioside-A) as a sugar replacement can be claimed to have low energy/calorie food. It can 
also be claimed as a free energy/calorie food because calorie value for these pickles were less than $4 \mathrm{kcal} / 100 \mathrm{~g}$, but not for xylitol as the calorie content was more than $40 \mathrm{kcal}$ per $100 \mathrm{~g}$, i.e. $83.68 \mathrm{kcal} / 100 \mathrm{~g}$.

\subsection{Ash}

Figure 5 shows that there was no significant different $(p>0.05)$ in percentage of ash among all the pickles prepared using different sweeteners. Overall, it can be concluded that only calcium and salt at the same amount added in each formulation and the original minerals present in the roselle calyces had contributed to the percentage of ash since all the sweetening agents only have $\mathrm{CHO}$ group.

\subsection{Crude fiber}

Figure 6 shows that there was no significant different $(p>0.05)$ among all the pickles in the percentage of crude fiber. This is because the crude fiber was only contributed by the roselle calyces used which were from the same source and variety.

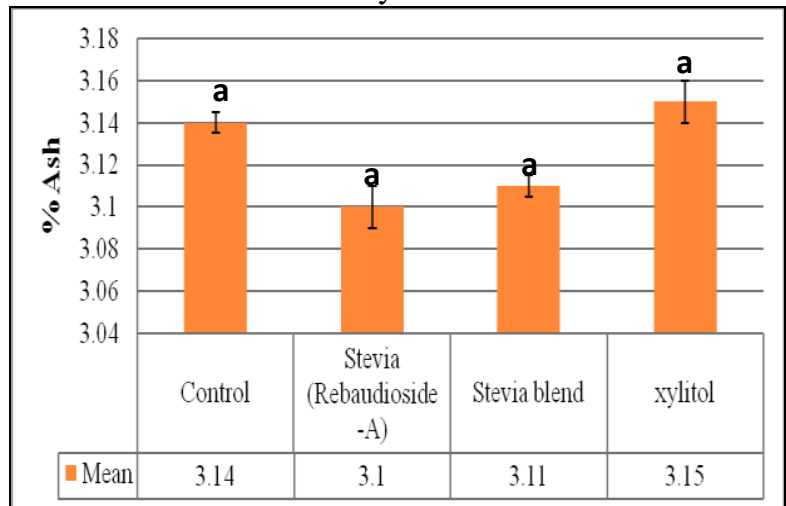

Figure 5: The percentage of ash in roselle pickles prepared using different sweeteners

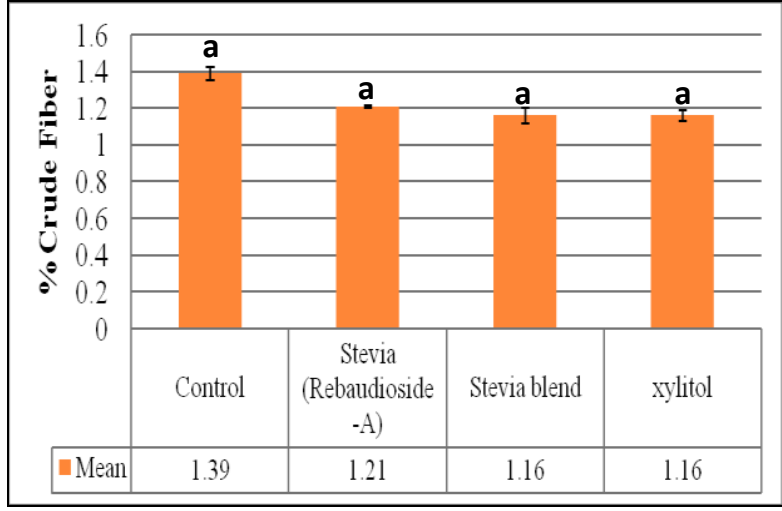

Figure 6: The percentage of crude fiber in roselle pickles prepared using different sweeteners

Values reported in means $(\mathrm{n}=3)$. Means followed by same letter are not significantly different at $p>0.05$.

\subsection{Ascorbic acid}

The usage of sweeteners as sugar replacement was not contributed to the differences in the ascorbic acid content. There was no significant difference $(p>0.05)$ of ascorbic acid in all the samples (Figure 7). However, ascorbic acid in roselle pickle (UKMR-2) was reduced approximately 75\% compared to the original content in fresh roselle UKMR-2, which was $15.2 \mathrm{mg}$ per 100g (Anon, 2009). This was because ascorbic acid was categorized as a water-soluble vitamin and easily destroyed or washed out during food preparation or storage (Anderson and Young, 2008).

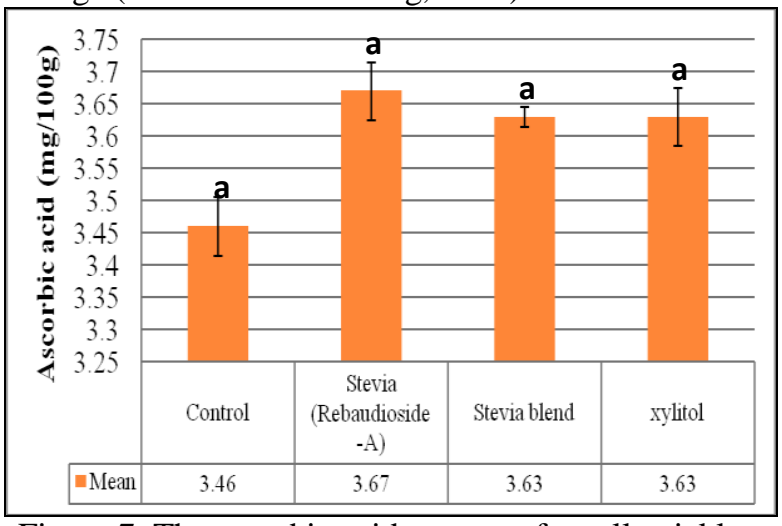

Figure 7: The ascorbic acid content of roselle pickles prepared using different sweeteners

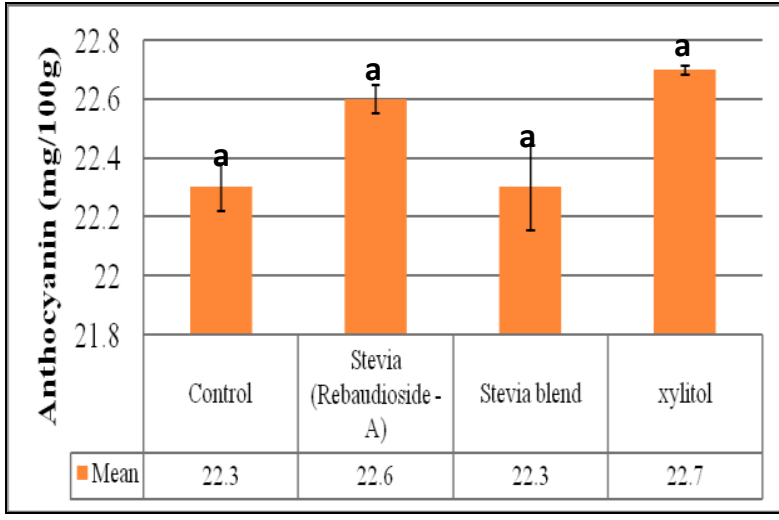

Figure 8: The anthocyanin content of roselle pickles prepared using different sweeteners

Values reported in means $(\mathrm{n}=3)$. Means followed by same letter are not significantly different at $p>0.05$.

\subsection{Anthocyanin}

Similar to the ascorbic acid, there was no significant different $(p>0.05)$ of anthocyanin content in all the pickles (Figure 8). However, the content of anthocyanin in roselle (UKMR-2) pickle was reduced approximately $90 \%$ as compared to the original content in fresh roselle UKMR-2, which was $230 \mathrm{mg} / 100 \mathrm{~g}$ (Anon, 2009). According to Giusti et al. (2001), anthocyanin is relatively unstable and often degrades during 
processing and storage and it is also categorized as a water-soluble flavonoid pigments (Wong et al., 2002). These factors contributed to the decreased in the anthocyanin during processing of roselle pickles.

\subsection{Microbiological quality}

For all the microbiological analyses of aerobic plate count, total coliform, yeast and mold count, Staphylococcus aureus count and Lactobacillus count. There was no microbial growths were observed in the roselle pickles as shown in Table 3. The absence of microbial growth was due to the high acidic condition in pickling solution and high concentration of brine solution during the salting process that had reduced the microbial load, and inhibited the growth of pathogen and spoilage microorganisms. High acidic condition of roselle pickle produced which was around $\mathrm{pH} 2$ (below than $\mathrm{pH}$ 4.6) inhibited the growth of pathogens and spoilage bacteria as well as some yeast and mold.

Another reason that microbes were not able to grow in this pickle was because of preservative effect of some sweetener such as xylitol. Xylitol had shown to inhibit the growth of food spoilage microorganisms at concentrations as low as $0.5 \%$ in solution. This occurs because it has a low molecular weight, so it exerts higher osmotic pressures and gives lower water activities than equivalent solutions of sucrose, so it can give a greater preservative effect (Bond, 2007; Mäkinen and Söderling, 1981). In this study, Lactobacillus was also not detected in the samples. This finding indicated that Lactobacillus was not viable at the end of fermentation of these roselle pickles.

Table 3: The microbiological quality of roselle pickles prepared using different sweeteners

\begin{tabular}{|c|c|c|c|c|c|}
\hline \multirow[t]{2}{*}{ Sample } & \multicolumn{4}{|c|}{$(\mathrm{CFU} / \mathrm{g})$} & \multirow[b]{2}{*}{$\begin{array}{c}\text { Lactobacillus } \\
\text { count }\end{array}$} \\
\hline & $\begin{array}{c}\text { Aerobic plate } \\
\text { count }\end{array}$ & $\begin{array}{c}\text { Total } \\
\text { coliform } \\
\end{array}$ & $\begin{array}{c}\text { Yeast and mould } \\
\text { count }\end{array}$ & $\begin{array}{c}\begin{array}{c}\text { Staphylococcus aureus } \\
\text { count }\end{array} \\
\end{array}$ & \\
\hline Control & ND & ND & ND & ND & ND \\
\hline Xylitol & ND & ND & ND & ND & ND \\
\hline Blend stevia & ND & ND & ND & ND & ND \\
\hline Stevia (rebaudiosid - A) & ND & ND & ND & ND & ND \\
\hline
\end{tabular}

$* \mathrm{ND}=$ Not detected $\left(<1 \times 10^{2}\right.$ Est. CFU/g)

\section{Conclusion}

From this study, xylitol was accepted as the best sweetener among sweeteners (xylitol, stevia (rebaudioside-A and stevia blend) for the replacement of sugar in the production of low calorie roselle pickles. This study also showed that there was no significant different $(p>0.05)$ in several physico-chemical properties such as $\mathrm{pH}$, texture, ash, crude fiber, ascorbic acid and anthocyanin content in roselle pickles prepared using different sweeteners. However, these three types of sweeteners showed significant different $(p<0.05)$ in term of colour, total soluble solid and total calorie content, where lighter and redder colour was observed as compared to control (sugar) pickle. For total soluble solid, control pickle using sugar gave the highest value followed by xylitol, stevia blend and the lowest was stevia (rebaudioside-A). For total calorie content, roselle pickles with sweeteners had more than three times less calorie content than the control pickle. Roselle pickle with stevia (rebaudiposide-A) and stevia blend had very low calorie content which were only $0.14 \mathrm{kcal} / 100 \mathrm{~g}$ and 2.23 $\mathrm{kcal} / 100 \mathrm{~g}$ respectively and can be claimed as low-energy/calorie food $(<40 \mathrm{kcal} / 100 \mathrm{~g})$. The microbiological tests on roselle pickles did not detect any growth of microorganisms indicating that all the roselle pickles were well preserved under brining process and high acidic condition ( $\mathrm{pH}$ below 3 ). Therefore, the chance of microbial spoilage is very low.

\section{Acknowledgements}

The authors would like to acknowledge the Research Management and Innovation Centre, UMT for the financial support through TBKP grant, all the staffs at Food Science Lab, Postharvest Technology Lab and Plant Research Lab, School of Food Science and Technology, UMT and Faculty of Engineering Technology, UNIMAP for their commitment and helping hands as well as Roselle Special Interest Group (RSIG) UMT for the support.

\section{References}

[1]. Anderson, J. and Young, L. 2008. Water-Soluble Vitamins.In: Food and Nutrition Series. Colourado State University Extension.

[2]. Anon. 2011. Pickling. Cooksinfo [Online]. Available from: http ://www.cooksinfo.com/pickling [ Accessed 26 March 2011].

[3]. Anon. 2009. Pelancaran Tiga Jenis Roselle Baru. Risalah UKM, $23^{\mathrm{hb}}$ April. Bangi: Penerbitan Universiti Kebangsaan Malaysia.

[4]. Barbara, H.I. 2002. Wisconsin Safe Food Preservation Series: Homemade Pickles and Relishes. University of Wisconsin$\begin{array}{llll}\text { Extension Cooperative } & \text { Extension } & \text { Anline]. }\end{array}$ http://www.foodsafety.wisc.edu/assets/preservation/B2267_Pickles_08.pdf [Accessed 27 December 2011] 
[5]. Bell, C., Neaves, P., Williams, A.P. 2005. Food Microbiology and Laboratory Practice. United Kingdom. Blackwell Science. Pp. 18-29.

[6]. Bond, M. 2007. Xylitol In: Wilson, R. (Ed.) Ingredients Handbook Sweeteners. $3^{\text {rd }}$ ed. UK: Blackwell Publishing Ltd. Pp 251 - 265.

[7]. Bond, M and Dunning, N. 2006. Xylitol. In: Mitchell, H. (Ed) Sweeteners and Sugar Alternatives in food Technology.UK: Blackwell Publishing Ltd. Pp 295-317.

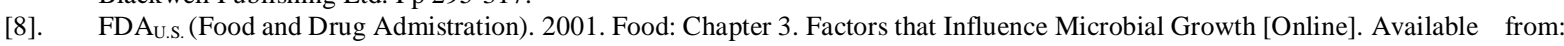
http://www.fda.gov/food/scienceresearch/researchareas/safepracticesforfoodprocesses/ucm094145.htm.

[9]. Garcia, J.M., Herrera, S. and Morilla, A. 1996. Effects of postharvest dips in calcium chloride on strawberry. Journal of Agricultural and Food Chemistry 44: $30-33$.

[10]. Giusti, M.M. and Wrolstad, R.E. 2001. Characterization and Measurement of Anthocyanins by UV-Visible Spectroscopy: Current Protocols in Food Analytical Chemistry F1.2.1-F1.2.13. John Wiley \& Sons, Inc. [Online]. Available from: http://www.nshtvn.org/ebook/molbio/Current\%20Protocols/CPFAC/faf0102. pdf

[11]. Herti, M. and Luis ,K. 2009. Khasiat dan Manfaat Rosel. Yusri, R. (Ed). Kuala Lumpur: Synergy Media. 40p.

[12]. Hui.Y.H., Sue Ghazala, Dee M. Graham, Murell K.D., Wai - Kit Nip. 2004. Handbook of Vegetable Preservation and Processing. Marcel Dekker, Inc. New York. Pp 179 - 181, 231 - 235.

[13]. Ibrahim, R., Hoon, G.Y., and Lani, M.N. 2014. New development of Pasteurised Roselle (Hibiscus sabdariffa L. 'UKMR-2') pickles. IOSR Journal of Applied Chemistry, 7(9), Ver. II, (Sep 2014), PP 01-08.

[14]. Jagota, S.K. and Dani, H.M. 1982. Analytical Biochemistry. Published by Elsevier Inc. India. Pp 178-182.

[15]. Jenat, D. and Jan, M.C. 2007. Stevioside. In: Wilson, R. (Ed.) Ingredients Handbook Sweeteners. $3^{\text {rd }}$ ed. UK: Blackwell Publishing Ltd. Pp $101-108$.

[16]. Kusakabe, I., Watanabe, S., Morita, R., Terehara, M. and Murakami, K. 1992. Formation of a transfer product from stevioside by the cultures of Actinomycetes. Bioscience, Biotechnology, and Biochemistry, 56 (2): 233-7.

[17]. Malcolm ${ }^{1}$, W. Kearsley and Ronald C. Deis. Maltitol and Maltitol Syrups. 2006. In: Mitchell, H. (Ed) Sweeteners and Sugar Alternatives in food Technology. UK: Blackwell Publishing Ltd. p 297.

[18]. Malcolm 2 , W. Kearsley and Ronald C. Deis. . 2006. Sorbitol and Mannitol. In: Mitchell, H. (Ed) Sweeteners and Sugar Alternatives in food Technology. UK: Blackwell Publishing Ltd. Pp 249-261.

[19]. Malaysia Food Regulations. 1985. Rule 347: Pickle. In: Food Act 1983 (Act 281) \& Regulations (Until 15 ${ }^{\text {th }}$ March 2011). $\quad$ Legal Research Board (Ed). Petaling Jaya, Selangor: International Law Book Services. p 230.

[20]. Malaysia Food Regulations. 1985. Rule 118 (3) and 118 (3): Stevia Extract and Stevia Enzymatic Modification. In: Food Act 1983 (Act 281) \& Regulations (Until 15 ${ }^{\text {th }}$ March 2011). Legal Research Board (Ed). Petaling Jaya, Selangor: International Law Book Services. Pp 140-141.

[21]. Malaysia Food Regulations. 1985. Rule 132 A (2): Artificial Sweetener. In: Food Act 1983 (Act 281) \& Regulations (Until 15 March 2011). Legal Research Board (Ed). Petaling Jaya, Selangor: International Law Book Services. Pp 146 - 150.

[22]. Malaysia Food Regulation. 1985. The Fifth A table (rule 18c), List I, Conditions of nutrient content for purpose of dietary claims. In: Food Act 1983 (Act 281) \& Regulations (Until 15 ${ }^{\text {th }}$ March 2011). p 271.

[23]. Mäkinen, K.K. and Söderling, E. 1981. Effect of xylitol on some food-spoilage microorganisms. Journal of Food Science. 46 : 950.

[24]. Musa, Y., Engku Ismail, E.A. and Yahya, H. 2006. Manual Teknologi Penanaman Rosel. $1^{\text {st }}$ ed. Kuala Lumpur: Penerbit Institut Penyelidikan dan Kemajuan Pertanian Malaysis (MARDI). 28p.

[25]. Noor Syahira, N. 2010. Pemanis Semulajadi dari Pokok Stevia. Majalah Agromedia: Bil 30. Pp 12-14.

[26]. Roberts, T.A., Cordier, J.-L., Gram, L., Tompkin, R.B., Pitt, J.I., Gorris, L.G.M. and Swanson, K.M.J. 2005. Vegetables and Vegetable Products. In: Microorganisms In Foods 6, Microbial Ecology of Food Commodities $.2^{\text {nd }}$ ed. New York: Kluwer Academic/Plenum Publishers. Pp. 277-325 [online]. Available from: http://www.scribd.com/doc/46855241/Micro-Organisms-inFoods [Accessed 21 November 2011)

[27]. Saltmarsh, M. 2000. Enssential Guide to Food Additives. $1^{\text {st }}$ ed. England: Leatherhead Publishing. p 8,155, $277,287$.

[28]. Wong, P.K., Yusof, S., Ghazali, H.M. and Che Man, Y.B. 2002. Physico-chemical characteristic of roselle (Hibiscus sabdariffa L.). Journal of Nutrition and Food Science. 32 (2): 68-73.

[29]. Yamaomoto, K., Yoshikawa, K. and Okada, S. 1994. Effective Production of Glycosyl-stevioside by alpha-1,6 transglucosylation of dextrin dextranase. Bioscience, Biotechnology, and Biochemistry 58 (9): 1657-61. 